\title{
Small Mammal Abundance on Native and Improved Foothill Ranges, Utah
}

\author{
COURTNEY B. SMITH AND PHILIP J. URNESS
}

\begin{abstract}
Small mammal populations were sampled annually over 4 years in native plant communities and improved rangeland types. All species of rodents were relatively less abundant where western wheatgrass was the dominant vegetation, but other differences among types were specific to individual species. Due to speciesspecific habitat preferences, total rodent numbers were highest where both sagebrush and seeded vegetation occurred together, and total rodent blomass was slightly greater along this ecotone than in a pure sagebrush type. Small-scale type conversion projects designed to increase the diversity of seeded and native stands may maintain or increase rodent abundance where species with such dissimilar habitat requirements occur.
\end{abstract}

Brush control and removal of sagebrush (Artemisia spp.) and pinyon-juniper (Pinus-Juniperus) vegetation have been common practices on Intermountain Region rangelands. Estimates of the public lands treated in this area include some $1,330 \mathrm{~km}^{2}$ of various sagebrush control practices in Utah and Idaho (Vale 1974) and $1,350 \mathrm{~km}^{2}$ of pinyon-juniper chainings of Utah (Aro 1975, Payne 1980). While these estimates represent a small portion of the public lands in this region, treatments applied in large blocks have substantially altered the composition and form of vegetation in localized areas (Vale 1974).

Some wildlife managers have expressed reservations concerning the value of these range improvements for wildlife. Roberts (1975) generalized that the majority of native wildlife species are adapted to native plant communities and would not benefit from seedings of exotic grasses. Identification of animal species restricted to native vegetation and those with habitat requirements more compatable with these range improvements is then important in balancing wildlife needs with other resource uses. The large size, lack of interspersion of native and seeded types, and predominance of seeded monocultures in past conversion projects have also been criticized (International Association of Game, Fish, and Conservation Commissioners 1971, Vale 1974). Interspersion of seeded and native types in smaller units may alleviate some of these features perceived as undesirable. Treatments landscaped to increase the mixture of cover types may improve habitat for some species as an extension of classical principles of wildlife management (Urness 1978).

This paper reports a portion of small mammal studies undertaken at the Tintic Valley Experimental Pastures in central Utah from 1978 through 1981. Our objectives were to compare the relative abundance of small mammals among the existing vegetation types and to provide baseline data for comparison following potential future manipulations.

\section{Study Site}

The Tintic Valley Experimental Pastures are located in eastern Juab County, Utah, and typify Intermountain spring-fall ranges. They occupy the lower slopes of the East Tintic Mountains at

\footnotetext{
Authors are graduate student and associate professor, respectively, Range Science Department, Utah State University, UMC-52, Logan. 84322.

This article is submitted as Utah Agricultural Experiment Station journal paper number 2843.

The authors wish to acknowledge the assistance of David R. Anderson, Utah Cooperative Wildlife Research Unit in analysis of data, and Robert R. Parmenter, research assistant, Utah State University Biology Department, for his suggested refinements of the manuscript.

Manuscript received May 5, 1983.
}

elevations from 1,700 to $1,828 \mathrm{~m}$. Mean annual precipitation is approximately $360 \mathrm{~mm}$. Soils are Mollisols and Aridisols, and all have loamy to fine sandy loam textures in the upper horizons.

Beginning in 1948 approximately one-half of this 1,400 -ha site was treated to remove native sagebrush and woodland vegetation and seeded to introduced grasses in 28 -ha pastures. These improved pastures contain crested wheatgrass (Agropyron desertorum), tall wheatgrass (A. elongatum), and other exotic grasses in mixed and single-species stands. In some pastures seeded species have been replaced by western wheatgrass $(A$. smithii), a native dominant. Woody cover consists of scattered sagebrush (Artemisia tridentata ssp. tridentata) and rabbitbrush (Chrysothamnus spp.) plants, and some improved pastures contain intermittent windrows of pinyon (Pinus monophylla) and juniper (Juniperus osteosperma) slash.

The remaining 700 ha support plant communities dominated by pinyon, juniper and big sagebrush. Associated species include bitterbrush (Purshia tridentata), greasewood (Sarcobatus vermiculatus), western wheatgrass, and bluebunch wheatgrass (Agropyron spicatum). Perennial grass production is sparse in these low-condition ranges and has shown no improvement despite 13 years of grazing exclusion (West et al. 1984).

\section{Methods}

Small mammal abundance was sampled in 2 studies. Snap-trap transects were used to establish indices of species abundance among the various cover types present from 1978 through 1980. Live-trapping for estimation of small mammal population parameters was undertaken each summer from 1979 through 1981 in seeded and native areas considered most representative of type conversion practices at this location, and in a habitat complex containing portions of both seeded and native plant communities. All data reported here were taken in late summer (August and September) in ungrazed or lightly grazed areas.

\section{Snap-trapping}

Snap-trapping was conducted on $4 \quad 100$-m traplines surrounding a 1-ha sample area. Each trapline contained 10 stations at $10-\mathrm{m}$ intervals consisting of 2 commercial mouse traps and 1 rat trap baited with peanut butter and rolled oats. Trapping was repeated on 3 consecutive nights in each year. Two traplines were used as subsamples in each area in 1979 and 1980, but in 1981 only 1 trapline was used per location. Improved-pasture habitats sampled included crested wheatgrass, western wheatgrass and tall wheatgrass types, and a tall wheatgrass seeding containing slashpiles. Native plant community types included sagebrush and pinyonjunper stands. Only the sagebrush and crested wheatgrass types were replicated.

The numbers of individuals captured per trapline were compared among types for the most abundant species using analysis of variance with a repeated measures design following Winer (1971, p. 261). An implicit assumption is that differences in capture frequencies a mong a reas reflect unequal abundance rather than variations in capture probabilities. Where sample sizes were adequate, Chisquare tests comparing the number of captures across nights and over areas were used to detect departures in the pattern of removals suggesting such biases. As a further qualification, capture probabilities were estimated by area and year based on constant removal 
Table 1. Number of rodents by species and habitats, and total biomass for all individuals snap-trpped, 1978-1980, Tintic Valley Experimental Pastures.

\begin{tabular}{|c|c|c|c|c|c|c|c|c|c|}
\hline \multirow[b]{4}{*}{ Species } & \multicolumn{9}{|c|}{ Habitat } \\
\hline & \multicolumn{5}{|c|}{ Improved } & \multicolumn{4}{|c|}{ Native } \\
\hline & \multirow{2}{*}{$\begin{array}{c}\text { Tall } \\
\text { wheatgr. + } \\
\text { slashpiles }\end{array}$} & \multirow{2}{*}{$\begin{array}{c}\text { Tall } \\
\text { wheatgr. }\end{array}$} & \multicolumn{2}{|c|}{ Crested wheatgrass } & \multirow{2}{*}{$\begin{array}{l}\text { Western } \\
\text { wheatgr. }\end{array}$} & \multicolumn{2}{|c|}{ Sagebrush } & \multirow{2}{*}{$\begin{array}{l}\text { Pinyon- } \\
\text { juniper }\end{array}$} & \multirow[b]{2}{*}{ Total } \\
\hline & & & rep 1 & rep 2 & & rep 1 & rep 2 & & \\
\hline $\begin{array}{l}\text { Deer mouse } \\
\text { (Peromyscus maniculatus) }\end{array}$ & 189 & 106 & 96 & 43 & 45 & 165 & 73 & 104 & 821 \\
\hline $\begin{array}{l}\text { Great Basin pocket mouse } \\
\text { (Perognathus parvus) }\end{array}$ & 18 & 12 & 14 & 13 & 4 & 22 & 14 & 13 & 110 \\
\hline $\begin{array}{l}\text { Western harvest mouse } \\
\text { (Reithrodontomys megalotis) }\end{array}$ & 20 & 17 & 17 & 12 & 5 & 1 & 27 & 0 & 99 \\
\hline $\begin{array}{l}\text { Least chipmunk } \\
\text { (Eutamias minimus) }\end{array}$ & 4 & 0 & 0 & 0 & 1 & 9 & 9 & 1 & 24 \\
\hline $\begin{array}{l}\text { Pinyon mouse } \\
\text { (Peromyscus truei) }\end{array}$ & 0 & 0 & 0 & 2 & 1 & 4 & 0 & 12 & 19 \\
\hline $\begin{array}{l}\text { Ord kangaroo rat } \\
\text { (Dipodomys ordii) }\end{array}$ & 0 & 3 & 0 & 1 & 2 & 1 & 0 & 1 & 8 \\
\hline $\begin{array}{l}\text { Sagebrush vole } \\
\text { (Lagurus curtatus) }\end{array}$ & 1 & 0 & 1 & 0 & 1 & 0 & 2 & 0 & 5 \\
\hline $\begin{array}{l}\text { Cliff chipmunk } \\
\quad \text { (Eutamios dorsalis) }\end{array}$ & 0 & 0 & 0 & 0 & 0 & 0 & 0 & 1 & 1 \\
\hline $\begin{array}{l}\text { Total number } \\
\text { Total biomass (g) }\end{array}$ & $\begin{array}{r}232 \\
3444.4\end{array}$ & $\begin{array}{r}138 \\
2065.2\end{array}$ & $\begin{array}{r}128 \\
1825.5\end{array}$ & $\begin{array}{r}71 \\
1022.8\end{array}$ & $\begin{array}{r}59 \\
937.9\end{array}$ & $\begin{array}{r}202 \\
3238.2\end{array}$ & $\begin{array}{r}125 \\
1830.8\end{array}$ & $\begin{array}{r}132 \\
2094.7\end{array}$ & $\begin{array}{c}1087 \\
16459.5\end{array}$ \\
\hline
\end{tabular}

rates. The number caught each night was compared to expected distributions based on the proportions of the total number of individuals trapped for a series of constant capture probabilities. The probability corresponding to the minimum Chi-square value within the acceptance region $(p<0.05)$ was interpreted as evidence of fit for this assumption and the most appropriate constant capture probability estimate.

\section{Live-trapping}

Live-trapping was conducted on $12 \times 12$-station grids with $10-\mathrm{m}$ spacing between trap stations. Stations consisted of two $7.6 \times 7.6$ $\times 25.4 \mathrm{~cm}$ live traps baited with rolled oats and peanut butter. Trapping occurred over a period of 5 successive nights in each year. Traps were checked each morning and shut during the day. Captured animals were marked by toe-clipping. Locations sampled included a sagebrush type, a habitat complex located on the border of seeded and sagebrush types, and a separate crested wheatgrass seeding. In 1979 all sample areas were located within approximately $2 \mathrm{~km}$ of one another. Heavy livestock grazing in the crested wheatgrass portion of the habitat complex in 1980 necessitated use of an alternative site in 1980 and 1981.

Variability in captures due to behavioral responses (trap happiness and shyness), different nights, and other factors have been demonstrated for a variety of species in live-trapping studies. Population estimators insensitive to these variations in capture probabilities may produce biased and imprecise estimates (Otis et al. 1978). Estimates in this study were derived using the computer program CAPTURE (White et al. 1978). This program compares fit of the data to models based on changes in capture probabilities with time (model $\mathbf{M}_{t}$ ), behavioral responses, $\left(\mathbf{M}_{b}\right)$, heterogeneity among animals $\left(\mathbf{M}_{h}\right)$, only random variation $\left(\mathbf{M}_{0}\right)$ and combined sources of variability using Chi-square tests and discriminant function analysis. Population estimates are provided for some models. These methods and the relationship of these models to traditional population estimators are discussed by Otis et al. (1978).

In 1979 snap-trap grids were used to sample marked and unmarked animals in the sagebrush and habitat complex sites the night following conclusion of live-trapping. These data were used to calculate a Lincoln index (Otis et al. 1978) for verification of population estimates from live-trapping. Density estimates followed Otis et al. (1978), assuming an effective trapping area sur- rounding the grid equal to one-half the distance across the average home range area. Home range estimates followed Jennrich and Turner (1969). Total rodent biomass was calculated using average species weights from previous studies in related habitats (Balph 1973 p. 236-248). All results reported as statistically significant refer to probabilities lower than 0.05 except where noted.

\section{Results and Discussion}

\section{Snap-trapping}

The numbers of individuals of each species snap-trapped from 1978 through 1980 are shown in Table 1. Deer mice (Peromyscus maniculatus), Great Basin pocket mice (Perognathus parvus), and western harvest mice (Reithrodontomys megalotis) accounted for over $90 \%$ of all individuals captured in each location, except in the pinyon-juniper community where pinyon mice (Peromyscus truei) were relatively abundant. In addition, 28 desert cottontails ( $S y l v i-$ lagus audubonii) and two black-tailed jackrabbits (Lepus californicus) were also trapped. All but two lagomorphs were taken in native vegetation types or along slashpiles within the improved pastures. The number of lagomorphs captured and their distribution among native and seeded types does not reflect their abundance or use of the seeded pastures. Large numbers of these animals were observed feeding in the outer edges of the seeded pastures during the morning and evening hours on many occasions.

The hypothesis of equal captures of deer mice among all habitats for data pooled over years were not rejected $(p<0.66)$. Annual variation was highly significant $(p<0.01)$ due to substantially greater numbers in 1978 than in following years (Table 2). The interaction of years and types was significant at the 0.06 probability level. Comparisons within years (Table 2) indicate greater abundance of deer mice where woody cover occurred either as standing vegetation or slashpiles, and smaller annual fluctuations in the sagebrush community compared to seeded types. Frequencies of capture for deer mice were consistently low in the western wheatgrass community relative to seeded types, but were significantly lower only in 1978.

With but 2 exceptions additional analyses failed to indicate biases in these estimates of deer mice abundance qualifying these results. Independence of capture frequencies among areas and over nights for the 1978 data was rejected at the 0.10 probability level $\left(X^{2}=22.36,14\right.$ d.f.). Higher than expected captures during the first 
Table 2. Number of deer mice snap-trapped by year and habitat, Tintic Valley Experimental Pastures.

\begin{tabular}{lccc}
\hline \hline & \multicolumn{3}{c}{ Year } \\
\cline { 2 - 4 } Habitat & 1978 & 1979 & 1980 \\
\hline Improved pastures & & & \\
Tall wheatgrass + slashpiles & $60.5^{\mathrm{c}}$ & $27.0^{\mathrm{b}}$ & $14.0^{\mathrm{ab}}$ \\
Tall wheatgrass & $32.0^{\mathrm{b}}$ & $13.0^{\mathrm{ab}}$ & $16.0^{\mathrm{ab}}$ \\
Crested wheatgrass & $28.8^{\mathrm{b}}$ & $3.5^{\mathrm{a}}$ & $5.0^{\mathrm{a}}$ \\
Western wheatgrass & $10.5^{\mathrm{a}}$ & $8.0^{\mathrm{ab}}$ & $8.0^{\mathrm{ab}}$ \\
Native vegetation & & & \\
Sagebrush & $25.8^{\mathrm{b}}$ & $21.5^{\mathrm{b}}$ & $24.5^{\mathrm{b}}$ \\
Pinyon-juniper & $28.0^{\mathrm{b}}$ & $21.5^{\mathrm{b}}$ & $5.0^{\mathrm{a}}$ \\
Annual averages & 30.9 & 15.8 & 12.1 \\
\hline
\end{tabular}

IValues followed by the same letter do not differ significantly $(p<0.05$, Least Significant Difference test) from others in the same column. Data for 1978 and 1979 are averages of subsamples.

night of sampling in the pinyon-juniper type, and greater numbers in the last night in crested wheatgrass replicate 2 , accounted for the bulk of the deviations. Corresponding capture probability estimates were 0.62 and 0.20 for the pinyon-juniper type and this seeded pasture, respectively, and were the highest and lowest probabilities for all data that could be fit to constant capture probability curves. This indicated that nearly all of the deer mice in the pinyon-juniper type in this year were sampled, but that a considerable proportion remained untrapped in this crested wheatgrass seeding. The remaining data for 1978 and that for 1979 showed little difference in estimated capture probabilities. Data for 1980 were insufficient for these comparisons.

The number of pocket mice captured (Table 1) differed significantly among areas at the 0.10 probability level $\left(X^{2}=13.49,7\right.$ d.f. $)$, due to fewer captures in the western wheatgrass pasture than all other types $\left(\mathrm{X}^{2}=6.22,1\right.$ d.f.). Harvest mice were absent or occurred only infrequently in the pinyon-juniper type and sagebrush replicate 1 . These areas contained more bare ground than other habitats, suggesting that lack of herbaceous vegetation limited the distribution of this species. Chi-square tests comparing totals among other habitats rejected independence $\left(\mathrm{X}^{2}=33.72,5\right.$ d.f. $)$. Captures in the seeded pastures were significantly greater than in the western wheatgrass type $\left(\mathrm{X}^{2}=8.62,1\right.$ d.f. $)$, but were higher in sagebrush replicate 2 relative to seeded areas $\left(X^{2}=4.19,1\right.$ d.f. $)$. Annual variation in the numbers captured was substantial at all locations. Although sagebrush replicate 2 produced the greatest total number of harvest mice, none were recorded there in 1980. Pinyon mice and least chipmunks (Eutamias minimus) were captured primarily in the pinyon-juniper and sagebrush communities, respectively.

Total rodent biomass and total rodent numbers in the western wheatgrass type and crested wheatgrass replicate 2 were only one- half to one-third as large as in other habitats (Table 1). Among the remaining improved and native types the range for these values was similar. Either total reflects the predominance of deer mice in the catch in all areas.

\section{Live-trapping}

Deer mice were the most abundant species captured in livetrapping. The number taken in 1980 and 1981 in the crested wheatgrass seeding were insufficient for tests of model assumptions in CAPTURE. In all other instances population estimates were obtained satisfying hypothesis tests provided in that program, or showing close agreement between the most appropriate estimates and Lincoln index estimates from snap-trapping in the same locations on an additional night. Population estimates, density estimates, and numbers of deer mice captured in each year and habitat segment are shown in Table 3. Differences in the magnitude of confidence intervals among population estimates is probably due to estimators rather than variability in the data, per se. Variances obtained using model $\mathrm{M}_{\mathrm{h}}$ are likely underestimated (Otis et al. 1978). Neither population nor density estimates showed consistent differences in deer mice abundance between the habitat complex and sagebrush types. Deer mice density was significantly greater in the sagebrush type than the habitat complex in $1980(z=4.54)$, but lower in $1981(z=4.05)$. The crested wheatgrass seeding had produced lower density than either site containing shrub cover in 1979 , and fewer individuals in remaining years.

The numbers of individuals of each species captured in livetrapping are shown by year in Table 4. Reliable population estimates could not be obtained for harvest mice and pocket mice in all locations due to small sample sizes and combined sources of variation in capture probabilities. Estimates were obtained for pocket mice in 3 areas based on model $M_{b}$. Population estimates with $95 \%$ confidence intervals were $25 \pm 13$ pocket mice in the crested wheatgrass habitat in $1979,44 \pm 12$ in the habitat complex in 1980 , and $15 \pm 1$ in the complex segment in 1981. Corresponding density estimates were $7.4 \pm 6.7$ animals per hectare in the crested wheatgrass seeding and $16.9 \pm 9.9$ and $6.3 \pm 4.0$ in the habitat complex in 1980 and 1981 , respectively.

The numbers of pocket mice and harvest mice captured in the sagebrush community were consistently low compared to other habitat segments (Table 4). Higher numbers of individuals of these 2 species in the habitat complex in 1980 and 1981 compared to the initial year of study probably reflect site differences among locations sampled. In view of this site variability and annual fluctuations, assessment of greater or lesser abundance in the crested wheatgrass type relative to the habitat complex is not justified for these species. Least chipmunks were recorded only in the sagebrush habitat and the sagebrush-dominated portion of the habitat complex. Closing of traps during the day no doubt reduced captures for this diurnal species, but their absence in the seeded plant communities further substantiates a strong preference for native vegetation types in this location.

Table 3. Population parameters for deer mice by habitat segment and year, Tintic Valley Experimental Pastures.

\begin{tabular}{|c|c|c|c|c|c|c|}
\hline Type & Year & Number captured & $\begin{array}{l}\text { Population estimate } \\
( \pm 95 \% \mathrm{CI})\end{array}$ & Model! & $\begin{array}{l}\text { Effective area (ha.) } \\
( \pm 95 \% \mathrm{CI})\end{array}$ & $\begin{array}{c}\text { Density (no./ha.) } \\
\text { ( } \pm 95 \% \mathrm{Cl})\end{array}$ \\
\hline Sagebrush & $\begin{array}{l}1979 \\
1980 \\
1981\end{array}$ & $\begin{array}{l}55 \\
45 \\
18\end{array}$ & $\begin{array}{l}65 \pm 8 \\
55 \pm 17 \\
22 \pm 6\end{array}$ & $\begin{array}{l}\mathbf{M}_{\mathbf{h}} \\
\mathbf{M}_{\mathbf{b}} \\
\mathbf{M}_{\mathbf{h}}\end{array}$ & $\begin{array}{l}2.68 \pm 1.1 \\
2.71 \pm 0.8 \\
2.46 \pm 0.5\end{array}$ & $\begin{array}{r}24.2 \pm 14.7 \\
20.3 \pm 10.7 \\
9.0 \pm 3.5\end{array}$ \\
\hline $\begin{array}{l}\text { Habitat } \\
\text { Complex }\end{array}$ & $\begin{array}{l}1979 \\
1980 \\
1981\end{array}$ & $\begin{array}{l}65 \\
21 \\
46\end{array}$ & $\begin{array}{l}74 \pm 8 \\
21 \pm 2 \\
67 \pm 36\end{array}$ & $\begin{array}{l}\mathbf{M}_{\mathbf{h}} \\
\mathbf{M}_{\mathrm{o}} \\
\mathbf{M}_{\mathrm{b}}\end{array}$ & $\begin{array}{l}2.65 \pm 0.9 \\
2.90 \pm 1.4 \\
2.98 \pm 1.1\end{array}$ & $\begin{array}{r}28.0 \pm 15.0 \\
7.2 \pm 5.6 \\
22.5 \pm 18.3\end{array}$ \\
\hline $\begin{array}{l}\text { Crested } \\
\text { Wheatgrass }\end{array}$ & $\begin{array}{l}1979 \\
1980 \\
1981\end{array}$ & $\begin{array}{r}22 \\
4 \\
6\end{array}$ & $\begin{array}{c}23 \pm 3 \\
\square\end{array}$ & $\underline{\mathbf{M}_{\mathbf{h}}}$ &.$\underbrace{3.41 \pm 1.0}$ & $\underbrace{6.7 \pm 3.5}$ \\
\hline
\end{tabular}

'Model refers to those presented in Otis et al. (1978).

${ }^{2}$ Habitat complex located on boundary between sagebrush and crested wheatgrass types. 
Table 4. Number of rodents live-trapped by habitat segment and year, Tintic Valley Experimental Pastures.

\begin{tabular}{|c|c|c|c|c|c|c|c|c|c|c|c|c|c|}
\hline \multirow[b]{3}{*}{ Species } & \multicolumn{13}{|c|}{ Habitat segment } \\
\hline & \multicolumn{4}{|c|}{ Crested wheatgrass } & \multicolumn{4}{|c|}{ Sagebrush } & \multicolumn{4}{|c|}{ Habitat complex ${ }^{1}$} & \multirow{2}{*}{$\begin{array}{l}\text { Grand } \\
\text { total }\end{array}$} \\
\hline & 1979 & 1980 & 1981 & Total & 1979 & 1980 & 1981 & Total & 1979 & 1980 & 1981 & Total & \\
\hline $\begin{array}{l}\text { Deer mouse } \\
\text { (Peromyscus maniculatus) }\end{array}$ & 22 & 4 & 6 & 32 & 55 & 45 & 18 & 118 & 65 & 21 & 46 & 132 & 282 \\
\hline $\begin{array}{l}\text { Western harvest mouse } \\
\text { (Reithrodontomys megalotis) }\end{array}$ & 50 & 10 & 6 & 66 & 2 & 2 & 1 & 5 & 9 & 17 & 11 & 37 & 108 \\
\hline $\begin{array}{l}\text { Great Basin pocket mouse } \\
\text { (Perognathus parvus) }\end{array}$ & 20 & 11 & 7 & 38 & 3 & 3 & 4 & 10 & 7 & 37 & 15 & 59 & 107 \\
\hline $\begin{array}{l}\text { Least chipmunk } \\
\text { (Eutamias minimus) }\end{array}$ & 0 & 0 & 0 & 0 & 4 & 6 & 13 & 23 & 4 & 1 & 5 & 10 & 33 \\
\hline $\begin{array}{l}\text { Ord kangaroo rat } \\
\text { (Dipodomys ordii) }\end{array}$ & 0 & 0 & 0 & 0 & $\mathbf{0}$ & 0 & 0 & 0 & 0 & 4 & 3 & 7 & 7 \\
\hline $\begin{array}{l}\text { Northern grasshopper mouse } \\
\text { (Onychomys leucogaster) }\end{array}$ & 1 & 0 & 0 & 1 & 0 & $\mathbf{0}$ & 0 & 0 & 2 & 0 & 0 & 2 & 3 \\
\hline $\begin{array}{l}\text { Pinyon mouse } \\
\text { (Permomyscus truei) }\end{array}$ & 0 & 0 & 1 & 1 & 0 & 1 & 0 & 1 & 0 & 1 & 0 & 1 & 3 \\
\hline $\begin{array}{l}\text { Sagebrush vole } \\
\text { (Lagurus curtatus) }\end{array}$ & 0 & $\mathbf{0}$ & 0 & $\mathbf{0}$ & 0 & 0 & 0 & 0 & 0 & 0 & 3 & 3 & 3 \\
\hline $\begin{array}{l}\text { Desert woodrat } \\
\text { (Neotoma lepida) }\end{array}$ & 0 & 0 & 0 & $\mathbf{0}$ & 0 & 0 & 0 & 0 & 1 & 0 & $\mathbf{0}$ & 1 & 1 \\
\hline Total & 93 & 25 & 20 & 138 & 64 & 57 & 36 & 157 & 88 & 81 & 83 & 252 & 547 \\
\hline
\end{tabular}

'Habitat complex located on boundary between sagebrush and crested wheatgrass types.

Total numbers of individuals of all species in the habitat complex were greater than those in either pure type (Table 4). Equal abundance of deer mice and least chipmunks in this area relative to the sagebrush type, and similar numbers of pocket and harvest mice compared to the crested wheatgrass seeding accounted for the bulk of this difference. Thus, greater total rodent numbers in this segment appear to be the result of an additive effect of combined vegetation cover for species with different habitat affinities. Although more species were recorded along this ecotone than in either pure type, the occurrence of most remaining species is not consistent. Soil texture or bare ground on a road running through the habitat complex may also have influenced the occurrence of Ord kangaroo rats (Dipodomys ordii). These features are important for this species at other locations (Larrison and Johnson 1973, Johnson 1982).

Excluding the larger species captured only infrequently, biomass of all rodents in the habitat complex was slightly greater than that in the sagebrush type (Table 5). Lower biomass totalled over all

Table 5. Total biomass (s) for all apecies captured in live-trapping by year and habitat segment, Tintic Valley Experimental Pastures.

\begin{tabular}{lcccc}
\hline & \multicolumn{4}{c}{ Year } \\
\cline { 2 - 5 } Habitat Segment & 1979 & 1980 & 1981 & Total \\
\hline Crested & 1033.3 & 309.0 & 260.6 & 1602.9 \\
$\begin{array}{l}\text { wheatgrass } \\
\text { Sagebrush }\end{array}$ & 1017.4 & 938.1 & 728.1 & 2683.6 \\
$\begin{array}{l}\text { Habitat } \\
\text { complex' }\end{array}$ & 1322.2 & 1078.4 & 1220.6 & 3621.2 \\
\hline
\end{tabular}

IHabitat complex located on boundary between crested wheatgras and sagebrush types. Excludes Ord kangaroo rats and desert woodrat.

years in the sagebrush habitat was due largely to the difference in 1981. Estimated biomass in the crested wheatgrass seeding was similar to that in other habitat segments only in 1979 when harvest and pocket mice were numerous. In the following 2 years it was substantially lower than that in the other areas studied.

\section{Summary and Conclusions}

Although annual variations and differences in sampling methods and sites have produced some contradictions, these studies do not support the conclusion that type conversion of sagebrush and pinyon-juniper ranges to communities dominated by seeded grasses necessarily reduces small mammal abundance. Only in the pasture where seeded exotic grasses have been replaced by western wheatgrass were all rodent species captured in lower than average numbers. Smaller rodent abundance in this type may be due to lower total vegetation cover or lower vegetation height. Other differences in relative abundance were species-specific. Deer mice were more abundant in habitats containing woody cover. Pocket mice occurred in equal or greater numbers in seeded areas relative to native plant communities. Live-trapping and snap-trapping produced conflicting results of harvest mice. The number of individuals captured in removal sampling was greater in one sagebrush type than in the seeded areas, but captures with live-trapping were consistently higher in habitats containing crested wheatgrass. This contradiction is likely the result of localized annual fluctuations in harvest mice abundance. Their absence from low-condition native ranges lacking herbaceous cover, and greater abundance in seeded habitats sampled by live-trapping show that they may benefit from type conversions. Pinyon mice and least chipmunks occurred primarily in native community types. We find some supporting evidence for these generalizations in other studies in ungrazed areas (Black 1968, Turkowski and Reynolds 1970, Larrison and Johnson 1973, Reynolds and Trost 1980).

Due to these differences in habitat preferences among species, total rodent abundance increased where native and seeded plant communities occurred together, with slightly higher total rodent biomass. Interspersion of native and seeded vegetation and smallscale type conversions may help maintain habitat for species with more limited habitat requirements. Retention of downed trees as protective cover should also be considered as a positive means of maintaining habitat for these and other non-game wildlife. Removal of woody cover through burning or spraying in areas where western wheatgrass is dominant in the understory appears the least favorable vegetation manipulation for these species.

Future research of some related range-wildlife problems may benefit from developments in wildlife population analyses. The methods provided by CAPTURE offer advantages in the approach to model selection and refinements in statistical methods (Otis et al. 1978). However, we note that rigorous testing of these hypotheses will require larger sample size than observed in this study. A technique for direct density estimation recently described by And- 
erson et al. (1983) appears to be a useful alternative. Based on application of distance sampling methods, this procedure avoids some arbitrary assumptions implicit to other population and density estimates. These methods may provide more reliable estimates of animal abundance, and assist in assessing further complementary or conflicting range and wildlife relationships.

\section{Literature Cited}

Anderson, D.R., K.P. Burnham, G.C. White, and D.L. Otis. 1983. Density estimation of small-mammal populations using a trapping web and distance sampling methods. Ecol. 64:674-680.

Aro, R.S. 1975. Pinyon-juniper woodland manipulations with mechanical means. p. 67-75 In: The Pinyon-Juniper Ecosystem: a symposium. Utah State Univ. Coll. of Nat. Res. and Agr. Exp. Sta., Logan.

Balph, D.F., coordinator. 1973. Curlew Valley Validation Site Report. U.S. Int. Bio. Program - Desert Biome Res. Memor. 73-1. Utah State Univ. Logan.

Black, H.H. 1968. Populations of small rodents in relation to grazing by cattle on foothill rangelands. MS Thesis, Univ. of Utah.

International Association of Game, Fish and Conservation Commisuioners. 1971. Public land policy impact on fish and wildlife. Int. Ass. Fish \& Game Comm., Washington, D.C.

Jennrich, R.I. and F.B. Turner. 1969. Measurement of non-circular home range. J. Theor. Biol. 22:227-237.

Johnson, M.K. 1982. Response of small mammals to livestock grazing in southcentral Idaho. J. Range Manage. 35:51-53.
Larrison, E.J., and D.R. Johnson. 1973. Density changes and habitat affinities of rodents of shadscale and sagebrush associations. Great Basin Natur. 33:255-264.

Otis, D.L., K.P. Burnham, G.C. White, and D.R. Anderson. 1978. Statistical inference from capture data on closed animal populations. Wildl. Mono. No. 62.

Payne, J.F. 1980. A multi-site evaluation of pinyon-juniper chaining in Utah. MS Thesis, Utah State Univ. Logan.

Roberts, R.W. 1975. Evaluating the impacts of range treatment on vegetation. Wild. Res. Rep. No. 7, Oregon Wildl. Comm., Corvallis, Oregon.

Reynolds, T.D., and C.H. Trost. 1980. The response of native vertebrate populations to crested wheatgrass planting and grazing by sheep. J. Range Manage. 33:122-125.

Turkowski, F.J., and H.G. Reynolds. 1970. Response of small rodent populations to pinyon-juniper reductions on the Kiabab Plateau, Arizona. Southwest. Natur. 15:23-27.

Urness, P.J. 1978. Wildlife habitat manipulations in sagebrush ecosystems. P. 169-178. In: The Sagebrush Ecosystem: a symposium. Utah State Univ. Coll. Nat. Res. Logan.

Vale, T.R. 1974. Sagebrush conversion projects: an element of contemporary environmental change in the western United States. Biol. Cons. 6:274-284.

West, N.E., F.D. Provenza, P.S. Johnwon, and M.K. Owens. 1984. Vegetation changes after 13 years of livestock grazing exclusion on sagebrush semi-desert in central Utah. J. Range Manage. 37:262-264.

Winer, B.J. 1971. Statistical principles in experimental design. McGrawHill, New York, N.Y.

White, G.C., K.P. Burnham, D.L. Otis, and D.R. Anderson. 1978. User's guide for program CAPTURE. Utah State Univ. Press, Logan. 